\begin{tabular}{ll}
\hline 薬 & 物 \\
\hline
\end{tabular}

鼻アレルギーに対する麻黄附子細辛湯の効果

\begin{tabular}{|c|c|c|c|}
\hline & 淑宏 - 中井 & 義明·古谷 & 博之 \\
\hline 工崎 & 裕介・八川 & 公爾 · 田村 & 隆之 \\
\hline 上小 & 学・杉浦 & 欣一 - 井口 & 広言 \\
\hline & 義春 · 岡本 & 純一・久保 & \\
\hline
\end{tabular}

\title{
Clinical Effect of Mao-Bushi-Saishin-To in Patients with Obstinate Nasal Blockage due to Perennial Rhinitis
}

\author{
Yoshihiro Ohashi, Yoshiaki Nakai, Hiroyuki Furuya, \\ Yusuke Esaki, Koji Hachikawa, Takayuki Tamura, \\ Manabu Uekawa, Yoshikazu Sugiura, Hiroyoshi Iguchi, \\ Yoshiharu Ohno, Junichi Okamoto, Takeshi Kubo, \\ Midori Sugiura and Megumi Takeda \\ (Osaka City University Medical School)
}

The usefulness of the Chinese medicine "Mao-Bushi-Saishin-To" for perennial rhinitis was evaluated. All of 33 patients had obstinate nasal blockage which had continued for at least a year despite the administration of anti-allergic drugs for more than three months and/or treatment with hyposensitization for more than one year.

1) The rate of effectiveness (excellent or good) of Mao-Bushi-Saishin-To after two and four weeks was $77.4 \%$ and $84.8 \%$, respectively.

2) The rate of improvement (excellent or good) of nasal blockage were $77.4 \%$ after two weeks and $81.8 \%$ after four weeks.

3) The only side effect was mild constipation in $6.1 \%$.

Key words: Chinese medicine, perennial rhinitis, obstinate nasal blockage

はじめに

鼻アレルギーは I 型アレルギー反応に基づく，

くしゃ及発作，水性鼻汁，鼻閉を主症状とする 疾患であり, 直接生命の危険を伴うものではな
いが，反面患者の日常生活に障害をもたらすこ とが多く，また年々この疾患に罹患する患者数 が増加する傾向にあることから, 社会的な問題 とまでなりつつある。 
本疾患に対しては，まず原因となっている抗 原を明らかにし，その原因抗原からの回避やそ の除去を図ることがあるが，容易には実施し得 ない場合が多い。また，本疾患には特異的減感 作療法が汎用されて扣り，良好な成績が報告さ れている112)が，治療効果が得られるまでにか なりの期間が必要であり，医師と患者の両者に 治療に対する努力・協力関係が不可欠なものと なる。

薬物療法に関しては，近年種々の抗アレル ギー剂が開発され，本疾患をはじめ気管支喘息 などに対して重要な治療手段のひとつとなって いる.しかし，これらの薬剤で鼻アレルギーの 3 主徴と呼ばれるもののらちくしゃみ発作と鼻 汁は改善されることが多いが，鼻閉については それらに比べるとやや効果が得られにくい。こ のような場合には，下鼻甲介粘膜切除術などの 外科的治療法を適応することが考慮される314 が，手術を望まない場合や幼小児では手術が不 可能な場合もあり，鼻アレルギーの鼻閉症状に 対して有効な薬剤が望まれるところである.

漢方製剂である麻黄附子細辛湯は，肥満細胞 からの脱顆粒抑制，リポキシゲナーゼ活性抑制， ヒスタミン遊離抑制などの作用5) 8) を有するこ とが認められて扣り，また臨床で著者ら ${ }^{9)}$ ，中 島ら 10)，中井ら 11)により鼻アレルギーに対する 有効性と安全性が報告されている．特に鼻閉型 に分類された鼻アレルギーに対し有効性が高い

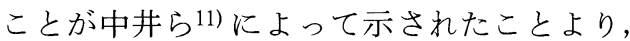

今回は難治性鼻閉を有する鼻アレルギー症例を 対象とした麻黄附子細辛湯エキスカプセルの臨 床効果を検討した。

\section{対象と方法}

1. 対象患者選別基準

昭和 63 年 9 月より平成元年 1 月までの間に当 科アレルギー外来を受診した患者のうち, 表 1 に示した選択基準の全てを満たし，難治性の鼻 閉を有する通年性鼻アレルギー患者を対象とし た。

通年性鼻アレルギー診断のための検査として は, (1)鼻鏡検査，(2)副鼻腔 $\mathrm{X}$ 線検查，(3)皮膚反 応検査, (4)鼻誘発反応検査, (5)鼻汁中好酸球数 検査，を施行した。アレルギー性の判定基準， 自覚症状の程度, 鼻鏡所見の程度の判定は奥田 の基準12)に準じた(表 $2 \sim 4$ ). また，鼻アレ ルギーの重症度の判定は表 5 の判定基準により, 重症, 中等症, 軽症, 無症状の 4 段階に分類し た。

\section{2. 方 法}

問診，アレルギー検査および一般臨床検査に よって本試験に適切な症例を選別した後, 試験 に参加することを同意した患者を対象症例とし て，以下に従い試験を施行した。

1）試験スケジュール

導入期間として 2 週間を設け，それまでに抗 アレルギー剤等の薬剤を使用していた患者につ いてはその使用を禁止し，導入期間の後半 1 週 間に搞ける自他覚症状を調査票に記入した。次

表 1 対象患者の選択基準

1.八ウスダストを抗原とする通年性鼻アレルギー患者

2 . 有病年数が少なくとも 1 年以上

3. 1 年以上の特異的減感作療法あるいは 3 力月以上の抗アレルギー剤等の投与に よっても鼻閉の改善しなかった患者

4. 年齢が 15 歳以上または体重が50キログラム以上

5. 季節性の鼻アレルギーを合併していない

6. 特異的減感作中の患者については維持量に達している

7. 鼻茸, 高度の慢性副鼻腔炎・急性上気道炎を合併していない

8. 本試験に参加することを承諾した患者 
表 2 アレルギー性の判定基準

\begin{tabular}{|c|c|c|c|c|c|}
\hline 種 類 & 程 度 & H+ & H & + & - \\
\hline \multirow{2}{*}{ 皮膚反応検査 } & 発 赤 & $41 \mathrm{~mm}$ 以上 & $40 \sim 21 \mathrm{~mm}$ & $40 \sim 21 \mathrm{~mm}$ & $20 \mathrm{~mm}$ 以下 \\
\hline & 膨 疹 & $15 \mathrm{~mm}$ 以上 & $14 \sim 10 \mathrm{~mm}$ & $9 \mathrm{~mm}$ 以下 & $9 \mathrm{~mm}$ 以下 \\
\hline \multicolumn{2}{|c|}{ 鼻汁中好酸球数検査 } & 群 在 & \#と＋の中間 & 弱拡でめだつ程度 & 0 \\
\hline \multicolumn{2}{|l|}{ 鼻誘発反応検査 } & $\begin{array}{c}\text { 症状 } 3 つ \\
\text { (くしゃ回数 } 6 \text { 回以上) }\end{array}$ & 症状 3 つ & 症状 $2 つ$ & 症状 1 つまたは 0 \\
\hline
\end{tabular}

表 3 自覚症状の程度

\begin{tabular}{|c|c|c|c|c|}
\hline 種 類 程 度 & H & H & + & - \\
\hline $\begin{array}{l}\text { くしゃみ発作 } \\
\text { (1 日の発作回数) }\end{array}$ & 10 回以上 & $9 \sim 5$ 回 & 4 回以下 & 0 \\
\hline 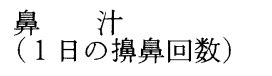 & 10回以上 & $9 \sim 5$ 回 & 4 回以下 & 0 \\
\hline 鼻閉 & $\begin{array}{l}\text { 鼻閉が非常に強く口 } \\
\text { 乎吸がかなりある }\end{array}$ & $\begin{array}{l}\text { 鼻閉が強くロ呼吸が } \\
\text { 時々ある }\end{array}$ & $\begin{array}{l}\text { 口呼吸は全くないが } \\
\text { 鼻閉あり }\end{array}$ & なし \\
\hline 嗅覚異常 & 無嗅覚 & 臭らが弱い & 少し弱い & 正常 \\
\hline 日常生活支障度 & $\begin{array}{l}\text { 仕事が手につかない } \\
\text { 程苦しい }\end{array}$ & H元＋の中間 & $\begin{array}{l}\text { 仕事には余り差しつ } \\
\text { かえない }\end{array}$ & 支障なし \\
\hline
\end{tabular}

表 4 鼻鏡所見の程度

\begin{tabular}{|c|c|c|c|c|}
\hline 種 類 程 度 & H & H & + & - \\
\hline $\begin{array}{l}\text { 下鼻甲介粘膜の腫脹 } \\
\text { 下鼻甲介粘膜の色調 } \\
\text { 鼻腔内の水性分泌量 } \\
\text { 鼻汁の性状 }\end{array}$ & $\begin{array}{l}\text { 中甲介みえず } \\
\text { （蒼白） } \\
\text { 鼻内に充満 } \\
\text { (水性) }\end{array}$ & 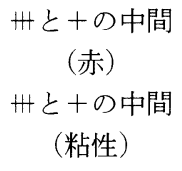 & $\begin{array}{c}\text { 中甲介中央まで } \\
\text { （薄赤） } \\
\text { 甲介に付着 } \\
\text { (膿性) }\end{array}$ & $\begin{array}{l}\text { なし } \\
\text { (正常) } \\
\text { なし } \\
\text { (なし) }\end{array}$ \\
\hline
\end{tabular}

表 5 鼻アレルギーの重症度の判定基準

\begin{tabular}{|c|c|c|c|c|c|c|}
\hline \multirow[t]{2}{*}{ 症 状 } & & \multicolumn{4}{|c|}{ くしゃみ発作または鼻汁 } & \\
\hline & 程 度 & H & $H$ & + & - & \\
\hline \multirow{2}{*}{ 鼻 } & H & 重 & 重 & 重 & 重 & 重: 重 症 \\
\hline & H & 重 & 中 & 中 & 中 & 中 : 中等症 \\
\hline \multirow{2}{*}{ 閉 } & + & 重 & 中 & 軽 & 軽 & 軽: 軽 症 \\
\hline & - & 重 & 中 & 軽 & 無 & 無 : 無症状 \\
\hline
\end{tabular}


いで， 4 週間試験薬剤を投与し，終了後直ちに 自他覚症状の再調査怙よびアンヶート調査を施 行した。 また，可能な症例に扔いては，投与開 始 2 週目にも自他覚症状を検査した。

2 ）使用薬剤，投与量ならびに投与方法 試験薬剤は麻黄附子細辛湯エキスカプセル (小太郎漢方製薬株式会社)を用い，投与量は 1 日 6 カプセル, 食後に 2 カプセルずつ 3 回で, 投与期間は 4 週間とした。本剤 1 カプセル中に は麻黄附子細辛湯のエキス $200 \mathrm{mg}$ を含有して いる。な扮，試験期間中は一切の併用薬の使用 を禁止したが，特異的減感作療法については継 続した.

3 ）効果判定の方法

本臨床試験では，麻黄附子細辛湯エキスカプ セルの臨床効果を下記の基準によって判定した.

(1) 症状改善度

試験薬剤投与後 2 週および 4 週目に，自他覚 症状の各項目の程度を投与前と比較し，その推 移により，下記の 3 段階で判定した。

著明改善： 2 段階以上の改善および消失した 場合

改善：1 段階の改善をみた場合

無 効：各項目別の程度で変化しなかった 場合または増悪した場合

(2) 全般有効度

試験薬剂投与後 2 週および 4 週目に，重症度 を投与前と比較し，その推移により，下記の 3 段階に評価した。

著効：重症度が 2 段階以上の改善または 無症状となった場合

有効 : 重症度が 1 段階改善した場合

無効：重症度の变化が認められなかった 場合または重症度が悪化した場合

(3) 概括安全度

全投薬期間を通じて随伴症状の有無などを総 合して，次の 5 段階に判定した。

安全：副作用と考兄られる症状がまった く認められなかった場合

汪汇安全：副作用と考えられる症状が認めら
れたが，軽度であり，試験続行上 問題がなかった場合

安全性にやや問題あり：副作用と考兄られる 症状が認められ，投薬の一時中断 が必要であった場合

安全性に問題あり：副作用と考えられる症状 が認められ，投薬の中止が必要で あった場合

不明：投薬開始後に新たな随伴症状が認 められたが，本試験薬剤との因果 関係が不明であった場合

（4）全般有用度

全般有効度および概括安全度を考慮して，(1) 極めて有用，(2)有用，(3)有用でない，の3 段階 で判定した.

\section{対象患者背景および成績}

1. 対象患者の背景

対象選択基準を満たした患者33名の背景を表 6 に示した. 性別は男13名, 女 20 名で, 年㱓は 14 歳から55歳までに分布していた。 また重症度に ついては，重症が26例 (78.8\%) で中等症は 7 例 (21.2\%) であった．本剤投与前の治療内容は経 ロ抗アレルギー剤のリザベン®などが 7 例, 局 所適応抗アレルギー煱のインタール®が 4 例, 点鼻用ステロイド剤のアルデシン®などが 9 例, 経口抗ヒスタミン剤を 6 例が使用していた。ま た14例が特異的減感作療法を受けていた。

対象33名に打壮る投薬前の自他覚症状，検査 所見の程度扣よび有症率を表 7 亿示した。本試 験の対象選択基準により，鼻閉症状，下鼻甲介 粘膜の腫脹度の症状が強い症例の多いことが認 められる。

2 . 成 績

1 ) 症状改善度

薬剤投与後 2 週目には 31 例の，また 4 週目に は全33例の各症状の調査を行い，それぞれの週 に拉ける改善度を表 8 に，また改善率(改善以 上の率)を図 1 に示した。

この結果を見ると, 改善率は今回の試験が前 治療で鼻閉が改善しなかった患者を対象にした 
ことを考慮すると，十分に満足すべき高いもの であると考光られる。また，すべての症状に拉 いて 2 週目に比べ 4 週目の方が改善率が高いこ とが認められる。しかも，鼻閉に関しては 2 週 目の時点ですでに 4 週目と注济同程度の改善率
を示していた。

\section{2 ）全般有効度}

薬剂投与後 2 週目では, 著効が 6 例 (19.4\%), 有効は18例 (58.1\%), 無効は 7 例 (22.6\%) で, 有効以上を示した症例は77.4\%であった。また，

表 6 症例の背景

\begin{tabular}{|c|c|c|c|}
\hline 項 & 目 & 分 類 & 症例数 $(\%)$ \\
\hline 性 & 別 & $\begin{array}{l}\text { 男 } \\
\text { 女 }\end{array}$ & $\begin{array}{ll}13 & (39.4) \\
20 & (60.6)\end{array}$ \\
\hline 年 & 齢 & $\begin{array}{c}10 \leqq \sim<19 \\
20 \leqq \sim<29 \\
30 \leqq \sim<39 \\
40 \leqq \sim<49 \\
\leqq 50\end{array}$ & $\begin{aligned} 4 & (12.1) \\
12 & (36.4) \\
5 & (15.2) \\
7 & (21.2) \\
5 & (15.2)\end{aligned}$ \\
\hline \multicolumn{2}{|c|}{ 外来 - 入院の別 } & $\begin{array}{ll}\text { 外 } & \text { 来 } \\
\text { 入 } & \text { 院 }\end{array}$ & $\begin{array}{r}33(100.0) \\
0 \quad(0.0)\end{array}$ \\
\hline \multicolumn{2}{|c|}{ 重 症 度 } & $\begin{array}{l}\text { 重 症 } \\
\text { 中等症 }\end{array}$ & $\begin{aligned} 26 & (78.8) \\
7 & (21.2)\end{aligned}$ \\
\hline \multicolumn{2}{|r|}{ 型 } & 鼻閉型 & $33(100.0)$ \\
\hline \multicolumn{2}{|c|}{ 発症 年 齢 } & $\begin{array}{c}10 \leqq \sim<19 \\
20 \leqq \sim<29 \\
30 \leqq \sim<39 \\
40 \leqq \sim<49 \\
\quad \leqq 50\end{array}$ & $\begin{array}{rr}2 & (6.1) \\
18 & (54.5) \\
8 & (24.2) \\
4 & (12.1) \\
1 & (3.0)\end{array}$ \\
\hline \multirow{2}{*}{ アレルギー性疾患 } & 家族歴 & $\begin{array}{ll}\text { 無 } & \text { 有 り } \\
\text { 有 }\end{array}$ & $\begin{array}{ll}21 & (63.6) \\
12 & (36.4)\end{array}$ \\
\hline & 既往症 & $\begin{array}{ll}\text { 無 } \\
\text { 有 }\end{array}$ & $\begin{array}{ll}16 & (48.5) \\
17 & (51.5)\end{array}$ \\
\hline \multirow{2}{*}{ 合 併 症 } & $\begin{array}{l}\text { アレルギー性 } \\
\text { 疾患 }\end{array}$ & $\begin{array}{ll}\text { 無 し } \\
\text { 有 り }\end{array}$ & $\begin{array}{rr}27 & (81.8) \\
6 & (18.2)\end{array}$ \\
\hline & その他の疾患 & $\begin{array}{ll}\text { 無 } \\
\text { 有 }\end{array}$ & $\begin{array}{r}33(100.0) \\
0 \quad(0.0)\end{array}$ \\
\hline \multicolumn{2}{|c|}{ 併 用 薬 } & $\begin{array}{ll}\text { 無 し } \\
\text { 有 }\end{array}$ & $\begin{array}{r}33(100.0) \\
0 \quad(0.0)\end{array}$ \\
\hline \multicolumn{2}{|c|}{ 既 治 療 薬* } & $\begin{array}{l}\text { 抗アレルギー剤(経口) } \\
\text { 抗アレルギー阂(局所) } \\
\text { ステロイド剤(点鼻) } \\
\text { 抗ヒスタミン剂(経ロ) } \\
\text { 特異的減感作療法 }\end{array}$ & $\begin{aligned} 7 & (21.2) \\
4 & (12.1) \\
9 & (27.3) \\
6 & (18.2) \\
14 & (42.4)\end{aligned}$ \\
\hline
\end{tabular}


表 7 投与開始前における各症状・検查の程度

\begin{tabular}{|c|c|c|c|c|c|}
\hline 項 目 程 度 & H & H & + & - & 計 \\
\hline くしゃみ発作 & $4(12.1)$ & $16(48.5)$ & $11(33.3)$ & $2(6.1)$ & 33 \\
\hline 鼻 & $6(18.2)$ & $12(36.4)$ & $10(30.3)$ & $5(15.2)$ & 33 \\
\hline 鼻閉 & $25(75.8)$ & $8(24.2)$ & $0(0.0)$ & $0(0.0)$ & 33 \\
\hline 下鼻甲介粘膜の腫脹 & $24(72.7)$ & $6(18.2)$ & $3(9.1)$ & $0(0.0)$ & 33 \\
\hline 下鼻甲介粘膜の色調 & $10(30.3)$ & $14(42.4)$ & $5(15.2)$ & $4(12.1)$ & 33 \\
\hline 鼻腔内の水性分泌量 & $4(12.1)$ & $12(36.4)$ & $13(39.4)$ & $4(12.1)$ & 33 \\
\hline 皮膚反応検査 & $5(15.2)$ & $20(60.6)$ & $4(12.1)$ & $4(12.1)$ & 33 \\
\hline 鼻汁中好酸球数検査 & $7(21.2)$ & $13(39.4)$ & $7(21.2)$ & $6(18.2)$ & 33 \\
\hline 鼻誘発反応検査 & $14(42.4)$ & $11(33.3)$ & $6(18.2)$ & $2(6.1)$ & 33 \\
\hline
\end{tabular}

数字は症例数，（）内は\%

表 8 症状の改善度

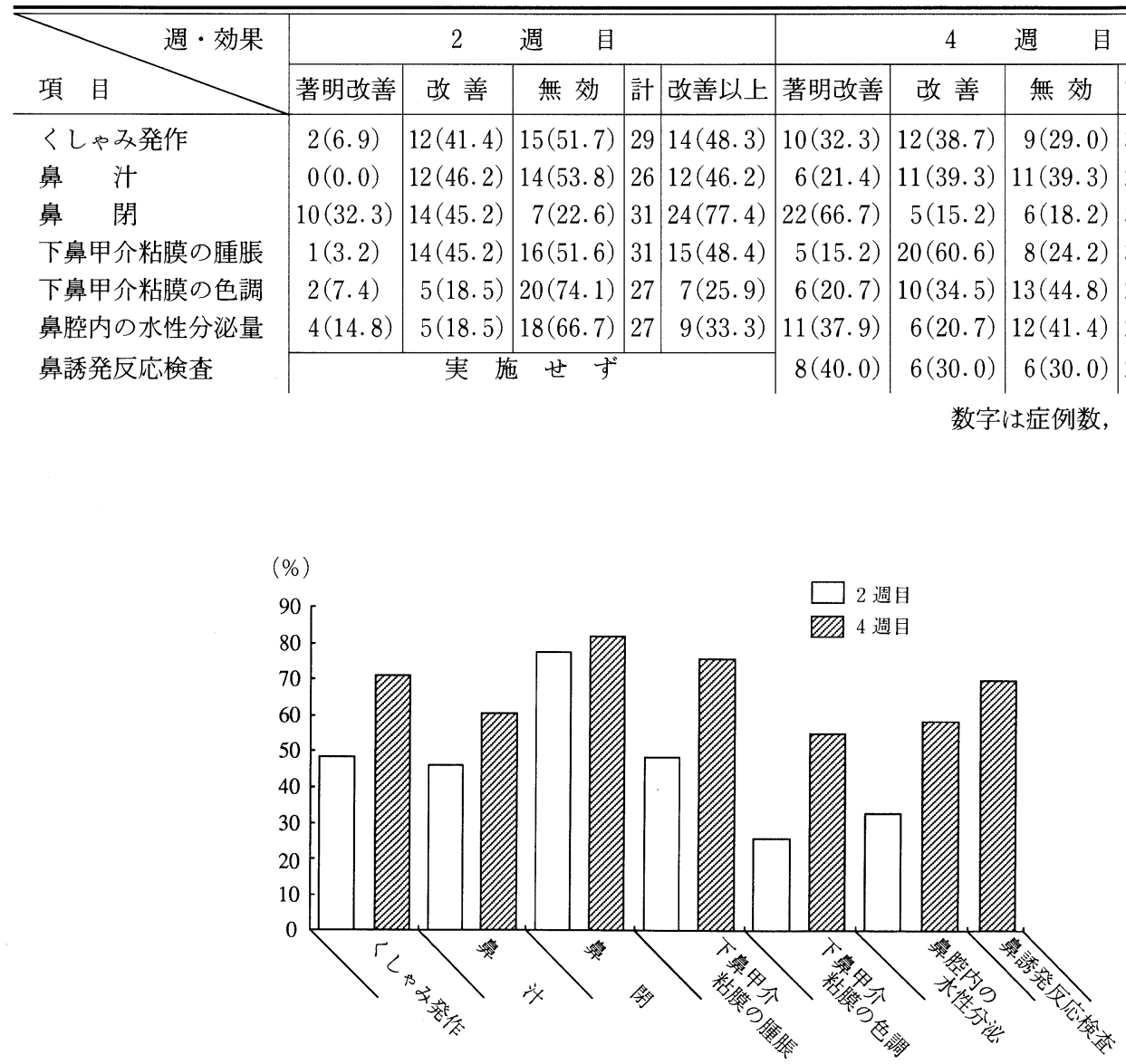

図 1 改善率 
4 週目に和ける全般有効度は33例中，著効は 19 例 (57.6\%)，有効は 9 例 (27.3\%)，無効は 5 例 (15.2\%)で，有効以上の成績は $84.8 \%$ の例で認 められた(表 9 ).

3 ) 概括安全度

投与開始後に新たに出現した随伴症状が33例 中 3 例 $(9.1 \%)$ に認められた。このらち 1 例は 軽度の下痢症状を示したが，本剤との因果関係 は明確にはできず，概括安全度は不明と判定し た。他の 2 例は便秘症状を示し，本薬剤との因 果関係が考えられたが，このららの 1 例では投 薬中止などの必要はなく，概括安全度はほぼ安 全と判定した。 たた，他の 1 例では数日間の投 薬中止の必要を認めたので, 安全性にやや問題 ありと判定した。したがって，安全と判定され た症例は33例中30例 (90.9\%) であり，注淁安全， 安全性にやや問題あり, 不明が各々 1 例 (3.0 \%)であった(表10).

\section{4 ）全般有用度}

全般有効度および概括安全度から総合的に判 定した全般有用度は，極めて有用は19例(57.6
$\%$ ，有用は 8 例 $(24.2 \%)$, 有用でないは 6 例 (18.2\%)で， $81.8 \%$ の例が有用以上と判定され た(表11)。

\section{考按}

古くより鼻アレルギーの治療には特異的減感 作療法が汎用されて和り，その有効性について は広く認められているところであるが，この療 法が奏効しない症例のあることも事実である。 このような症例や特異的減感作療法, 外科的治 療法の施行できない症例に対しては，いわゆる 抗アレルギー剂に代表される薬物治療が適応と なる．また近年，漢方薬が鼻アレルギーの治療 に用いられるよらになってきており，その代表 的なものとして小青竜湯が知られ，臨床試験で の成績から本疾患に対しての有效性が報告され ている131414。また薬理学的にも小青竜湯を構成 する生薬には抗ヒスタミン作用, IgE 抗体産生 抑制作用，血中ヒスタミン低下作用などを有す る事が明らかになり15)16)，臨床での成績を裏付 けるものである.しかし，いわゆる抗アレルギー 剂と同様に小青竜湯は鼻アレルギーの 3 主徴の

表 9 全般有効度

\begin{tabular}{c|r|r|r|l|c}
\hline \hline & 著 効 & 有 効 & 無 効 & 計 & 有 効以上 \\
\hline 2 週目 & $6(19.4)$ & $18(58.1)$ & $7(22.6)$ & 31 & $24(77.4)$ \\
4 週目 & $19(57.6)$ & $9(27.3)$ & $5(15.2)$ & 33 & $28(84.8)$
\end{tabular}

数字は症例数，（）内は\%

表 10 概括安全度

\begin{tabular}{|c|c|c|c|c|c|c|}
\hline 安 全 & ほぼ安全 & \begin{tabular}{|l|} 
安全性に \\
やや問題あり \\
\end{tabular} & \begin{tabular}{l|} 
安全性に \\
問題あり \\
\end{tabular} & 不 明 & 計 & ほぼ安全 \\
\hline $30(90.9)$ & $1(3.0)$ & $1(3.0)$ & $0(0.0)$ & $1(3.0)$ & 33 & $31(93.9)$ \\
\hline
\end{tabular}

数字は症例数，（）内は\%

表11 全般有用度

\begin{tabular}{|c|c|c|c|c|}
\hline 極めて有用 & 有 用 & 有用でない & 計 & 有用以上 \\
\hline $19(57.6)$ & $8(24.2)$ & $6(18.2)$ & 33 & $27(81.8)$ \\
\hline
\end{tabular}


らち、くしゃみ発作と鼻汁には有効であるが， 鼻閉に対しては必ずしも良好な成績は得られて いない。

一方, 麻黄附子細辛湯も抗アレルギー作用が 報告されている漢方薬の一つで，日笠ら5) は PCA 反応と皮膚接触過敏反応に打けるI 型抒 よび $\mathrm{N}$ 型アレルギーに対する抗アレルギー作用 を報告し，Yamahara ら ${ }^{6)}$ は Schultz-Dale 反応 を用いて，抗アレルギー作用を報告している. また，丹羽7）は好塩基球からのヒスタミン遊離 抑制作用とリポキシゲナーゼ活性抑制作用を， 柴田ら ${ }^{8)}$ は肥満細胞からの脱顆粒およびヒスタ ミン遊離抑制効果を報告している。麻黄附子細 辛湯の構成生薬は麻黄・附子・細辛の三種であ り, その個々の生薬についても抗アレルギー作 用を有することが薬理学的に証明されている. 江田ら ${ }^{17)}$ は麻黄にケミカルメディェーターや anaphylactic mediator の遊離抑制作用のある こと，細辛にはケミカルメディェーター遊離抑 制作用や抗ヒスタミン作用のあること, 柴田 ら ${ }^{8)}$ は麻黄に肥満細胞からの脱顆粒拉よびヒス タミン遊離抑制効果を認めている。これらによ り麻黄附子細辛湯は鼻アレルギーに対しても十 分効果を示すものと考兄られ, 本薬剤の鼻アレ ルギー治療への試みがなされ，その有効性が報

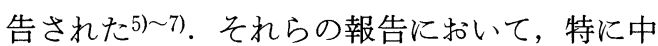
井ら11) は多施設で通年性鼻アレルギー症例に 対する麻黄附子細辛湯の効果を検討し，特に病 型が鼻閉型，〈しゃみ・鼻閉型を示すような， 鼻閉症状が強く現われている鼻アレルギー患者 に対しての効果が良好で，76.3\%に改善以上の 効果が得られたと報告している.

そこで今回，抗アレルギー剤や特異的減感作 療法によっても鼻閉の改善しなかった鼻アレル ギー患者に対する麻黄附子細辛湯エキスカプセ ルの臨床効果を検討した。試験開始前の症状に ついては，くしゃみ発作や鼻汁関する程度は 比較的軽度な症例が多く, 過半数の症例がこれ らの項目については軽症または無症状であった が，鼻閉症状については全症例が中等症以上で
あった。鼻閉症状の改善度についてみると本剤 投与開始 2 週目では $32.3 \%$ 亿著明改善， $77.4 \%$ に改善以上の効果が認められ，また 4 週目では $66.7 \%$ 著明改善， $81.8 \%$ 亿改善以上の効果が 認められた。中井ら11)の多施設での臨床試験 成績では 4 週間投与による鼻閉の改善度は 76.3 $\%$ と報告されて和り，今回の鼻閉症状の強い症 例に投与した場合にも同等以上の成績が得られ た。他覚所見である下鼻甲介粘膜の腫脹に括い ても, 今回の試験成績では 4 週目で $75.8 \%$ の症 例に改善以上の成績が得られ，中井ら ${ }^{11)}$ の報 告した $52.8 \%$ よも良好な成績であった。

また，重症度の推移による全般有効度につい て検討すると，有効以上の症例は 2 週目で77.4 $\% ， 4$ 週目では $84.8 \%$ と良好で，以前著者ら ${ }^{9)}$ の報告した $66.7 \%$ や井ら ${ }^{11)}$ の報告した 76.7 \%ょりもさらに優れた成績であり，これは今回 の試験が鼻閉症状を主訴とする患者を対象とし ているためと考えられた。 そこで，中井ら ${ }^{11}$ の報告における層別解析の結果の中で, 鼻閉型 敃よびくしゃみ・鼻閉型の 2 型のみの全般有効 度をみると有効以上は $88.0 \%$ であり，今回の試 験の成績の $84.8 \%$ と同様の結果であったと考え られる。

対象とした 33 例中 2 例に副作用と考兄られる 便秘症状の発現が認められたが，いずれも軽度 なものであり，本薬剤使用にあたって特に問題 となるとは考学られなかった。また 1 例に下痢 症状が認められたが，本剂との因果関係は薄い と考えられた。

鼻アレルギー症例に括ける鼻閉発現機序とし ては，アレルギー反応に伴ら鼻粘膜の浮腫性変 化が支持されているが，その他にも鼻粘膜に抏 ける非特異的な病態の関与していることが考兄 られる2て4)．鼻アレルギーに抢ける鼻閉に効果 的な薬剤の条件として，単と抗ヒスタミン作用 のみではなく抗ロイコトリェン作用や抗血小板 活性化因子作用など，ケミカルメディエーター 全般に作用しらることが必要であると考えられ ている.この点に関して本剤は前述のごとく, 
薬理学的検討で種々のメディエーターの遊離抑 制作用を有していること，また本剤の構成生薬 である麻黄に含まれるェフェドリンには，交感 神経のアルファ受容体刺激作用を介する充血や 浮腫の軽減作用があり, この点も本剤が鼻閉軽 減に有効であった理由の一つと考えられた。

\section{まとめ}

特異的減感作療法や抗アレルギー剂等の使用 によっても，鼻閉症状の改善されなかった33例 の通年性鼻アレルギー患者に麻黄附子細辛湯エ キスカプセルを投与し, 以下の成績を得た.

1. 全般有効度は本剂投与後 2 週目では77.4 \%に有効以上の成績が認められ，4 週目では 84.8\% に有効以上の成績が認められた.

2. 鼻閉症状については，2 週目で77.4\%に 改善以上の効果が認められ，4 週目では $81.8 \%$ の症例に改善以上の効果が認められた.

その他の症状についても, 既存の抗アレル ギー薬と同等の効果であった.

3 . 本剂との因果関係の示唆された副作用は 2 症例に認められたが，いずれも軽度の便秘症 状であった。

以上の成績より, 麻黄附子細辛湯エキスカプ セルは強い鼻閉症状を有する通年性鼻アレル ギーの治療薬として極めて有用であることが示 唆された.

\section{参考文献}

1) Ohashi $Y$, Nakai $Y$, Kihara $S$, et al : Housedust mite specific IgE, IgG1, and IgG4 antibodies in patients with perennial rhinitis. Ann Otol Rhinol Laryngol 96 : 434 437, 1987.

2) Ohashi $Y$, Nakai $Y$, Ikeoka $H$, et al : An increased ciliary beating frequency of nasal allergy mucosa following immunotherapy. Ann Otol Rhinol Laryngol 98 : 350 354, 1989.

3）大橋淑宏：鼻アレルギーと扮ける鼻閉の鼻粘膜 病態. 日耳鼻 $88: 384 \sim 387,1985$.

4）中井義明, 大橋淑宏 : 鼻アレルギーの局所免疫, 生理, 病態関する基礎的研究とその臨床応用. 病態生理 5 : 979 981, 1986.

5）日笠 穣, 夏秋 優, 大坪義和, 他 : 麻黄附子 細辛湯の抗アレルギー作用. 基礎と臨床 22 :
1743 1747, 1988.

6) Yamahara J, Kimata $M$, Sawada $T$, et al : Antiallergic effect of Mao-bushi-saisin-to and active principles of Aliasarum sieboldi. WAKAN-YAKU $3:$ 153 158, 1986.

7）丹羽勒負：麻黄附子細辛湯エキス散の薬理作用 機序 一特に抗アレルギー作用および抗酸化作 用についての検討一. 皮膚科紀要 $82: 193 \sim 209$, 1987.

8）柴田忠良, 杉山正夫：麻黄附子細辛湯エキスお よびその構成生薬の肥満細胞からのヒスタミン 遊離抑制作用. 和漢医薬学会誌 $6: 288 \sim 289$, 1989.

9）大橋淑宏, 中井義明, 箕輪靖弘, 他 : 鼻アレル ギーに対する麻黄附子細辛湯エキス散の臨床効 果. 基礎之臨床 $19: 6691 \sim 6697,1985$.

10）中島 理, 前田映子, 塚本祐壮, 他: 鼻アレル ギーに対する麻黄附子細辛湯エキス散の臨床効 果. 基礎と臨床 $20 ： 1277 \sim 1281,1986$.

11）中井義明, 大橋淑宏, 汇崎裕介, 他: 鼻アレル ギーに対する麻黄附子細辛湯の臨床効果の検討. 耳展 $33: 655 \sim 673,1990$.

12）奥田 稔：鼻アレルギー診療の実際 第 4 版 (奥田 稔編). 186 188頁, 金原出版, 東京, 1979.

13）岡崎英登, 川本英子, 原田康夫 : 鼻アレルギー に対する漢方ェキス製剤(小青竜湯)の臨床効果. 耳鼻臨床 $74: 367 \sim 380,1981$.

14）大橋淑宏, 頭司研作, 黒木幸一, 他: 鼻過敏症 に対する小青竜湯の臨床効果. 耳鼻臨床 76 : 2589〜2596, 1983.

15）栗山一男, 馬場広太郎, 奥沢裕二, 他 : 和漢薬 小青竜湯の鼻アレルギーに対する効果 一第 1 報 小青竜湯投与による血中 $\operatorname{IgE}$ ，ヒスタミン および c-AMP の変動一. アレルギー $29: 227$ $\sim 235,1980$.

16）鳥居敏明, 富岡托夫, 熊谷 朗：ラットの homocytotropic antibody $匚$ 対する甘草成分 (Lx) の抑制効果. 第22回日本アレルギー学会 総会抄録. 105 106頁, 1973.

17）江田昭英, 勝田栄二, 渡辺茂勝, 他 : 生薬の抗 アレルギー作用についての吟味. 日薬理誌 66 : 366 378, 1970.

\footnotetext{
/原稿受付 : 平成 4 年 1 月 30 日 原稿採択: 平成 4 年 3 月 11 日 別刷請求先 : 大橋淑宏

干545 大阪市阿倍野区旭町1-5-7

大阪市立大学医学部耳鼻咽喉科学教室
} 